\title{
Design of Web-Based Information System for the Bung Hatta University Professional Certification Institute (LSP)
}

\author{
Dony Novaliendry ${ }^{1}$, Afiful Azkia1* \\ 1Electronic Department, Informatics Education, Engineering Faculty, Universitas Negeri Padang, Indonesia \\ *Corresponding author: afifulazkia@gmail.com
}

\begin{abstract}
INTISARI
Sertifikasi profesi merupakan upaya memberikan pengakuan atas kompetensi yang dikuasai seseorang sesuai dengan standar kompetensi kerja yang dipersyaratkan. Lembaga Sertifikasi Profesi (LSP) Universitas Bung Hatta merupakan lembaga pelaksana kegiatan sertifikasi kompetensi yang mendapat lisensi dari Badan Nasional Sertifikasi Profesi (BNSP) untuk mensertifikasi mahasiswa dari berbagai bidang ilmu dan profesi yang ada di Universitas Bung Hatta. LSP Universitas Bung Hatta memiliki status LSP pihak kesatu lembaga pendidikan. Saat ini, proses pendaftaran sertifikasi di LSP Universitas Bung Hatta masih dilakukan secara manual, yaitu dengan mengisi beberapa formulir berupa kertas. Hal ini dirasa kurang efektif mengingat kemajuan teknologi pada saat sekarang ini. Dengan mengembangkan sistem informasi berbasis website hal tersebut dapat diatasi. Tujuan perancangan sistem informasi berbasis website ini adalah untuk menghasilkan sistem informasi yang dapat membantu proses sertifikasi dan dapat diakses oleh setiap user terkait kapan saja dan dimana saja. Sistem informasi ini dikembangkan menggunakan metode waterfall. Metode ini memiliki beberapa tahapan, yaitu tahap analisis kebutuhan, perancangan, implementasi, dan pengujian. Perancangan sistem informasi ini menggunakan pemodelan Unified Modelling Language (UML) dan diimplementasikan menggunakan framework Yii2 sebagai framework PHP dan MySQL sebagai Database Management System (DBMS). Perancangan sistem informasi ini menghasilkan Sistem Informasi LSP Universitas Bung Hatta berbasis web, yang berfokus pada proses administrasi awal.
\end{abstract}

Kata kunci: Framework Yii2, Sertifikasi Profesi, Sistem Informasi, UML, Waterfall.

\begin{abstract}
Professional certification is an effort to recognize a person's competence by the required work competency standards. Bung Hatta University Professional Certification Institute (LSP) is an agency implementing competency certification activities that have received a license from the National Professional Certification Agency (BNSP) to certify students from various fields of science and professions at Bung Hatta University. Bung Hatta University LSP has the status of the first party LSP educational institutions. The registration process for certification at the Bung Hatta University LSP is still done manually by filling in several paper forms. This is considered ineffective considering the current technological advances. By developing a website-based information system, this can be overcome. The purpose of designing a website-based information system is to produce an information system that can assist the certification process and can be accessed by any relevant user anytime and anywhere. This information system was developed using the waterfall method. This method has several stages, namely the needs analysis, design, implementation, and testing stage. The design of this information system used Unified Modeling Language (UML) and implemented using the Yii2 framework as a PHP framework and MySQL as a Database Management System (DBMS). The design of this information system resulted in a web-based Information System for Bung Hatta University LSP, which focused on the initial administrative process.
\end{abstract}

Keywords: Information System, Professional Certification, UML, Waterfall, Yii2 Framework.

\section{INTRODUCTION}

Professional certification is an effort to recognize a person's competence by the required work competency standards [1]. Article 18 of Law
Number 13, the Year 2003 concerning Manpower, mandates establishing a National Professional Certification Agency (BNSP) to carry out certification [2]. Furthermore, with Government Regulation No. 23/2004, BNSP was established [3]. 
In carrying out its duties, BNSP can delegate to Professional Certification Institutions (LSP). Bung Hatta University LSP is an implementing agency for competency certification activities that have received a license from BNSP to certify students from various fields of science and professions at Bung Hatta University. Bung Hatta University LSP has the status of the first party LSP educational institution [1].

The certification registration process at the Bung Hatta University LSP is still carried out manually, namely by filling in several paper forms, so that the candidates must visit the Bung Hatta University LSP to register. This is considered ineffective considering the current technological advances. By developing a website-based information system, this can be overcome. Existing forms can be replaced with digital documents. Then, the data that has been inputted will also be saved directly to the database and can be recalled at any time if needed.

The information system is a collection of computer hardware and software and human devices that will process data using the hardware and software [4]. Website-based information system design aims to simplify the information system because it can be accessed online. One of the programming languages used to build websites is the PHP programming language. PHP is a serverside programming language specifically designed for web-based application development [5]. Along with the times, various PHP frameworks were developed to make it easier for programmers in the website building process. The framework is a framework, or it can also be interpreted as a collection of scripts that can help application development in handling various programming problems such as connecting to databases, calling variables and files so that developers build applications faster [6]. So, the PHP framework is a framework that helps web developers in making webs using PHP scripts.

Many PHP frameworks have been developed, including the Laravel framework, CodeIgniter framework, and Yii2 framework. Each framework has advantages and disadvantages, but both have the goal of making it easier for programmers to build websites. One of the PHP frameworks features that makes the programmer's job easier is the code generator. The Yii2 framework includes a code generator called Gii. Gii is a module provided by the
Yii2 framework for generating various coding components such as models and controllers. This greatly facilitates the work of programmers in programming that has a model, view, controller (MVC) pattern. In addition to the model and controller generator, Gii also has a CRUD (Create, Read, Update, Delete) generator that makes it easy to manage data to and from the database. [7]. Therefore, the Yii2 framework is considered very suitable for developing this information system.

In information system design, database design is important. To produce good information, an information system must have a database that can manage data properly. This requires a database management software known as a Database Management System (DBMS). DBMS is software for controlling the creation, maintenance, processing, and use of large-scale data [8]. One of the most frequently used DBMS is MySQL. MySQL is the main choice for many software developers because of its advantages, namely, an easy-to-understand syntax and support for various programming languages such as C, C ++, Java, PHP, and Python [8].

\section{METHOD}

One of the software development methods is the waterfall method. The waterfall method is a sequential software development process in which progress is seen as continuously flowing downward (like a waterfall) through the phases of planning, modeling, implementation (construction), and testing [9]. In developing this information system, the waterfall method will be used [10]. The technique in question can be explained in the following figure.

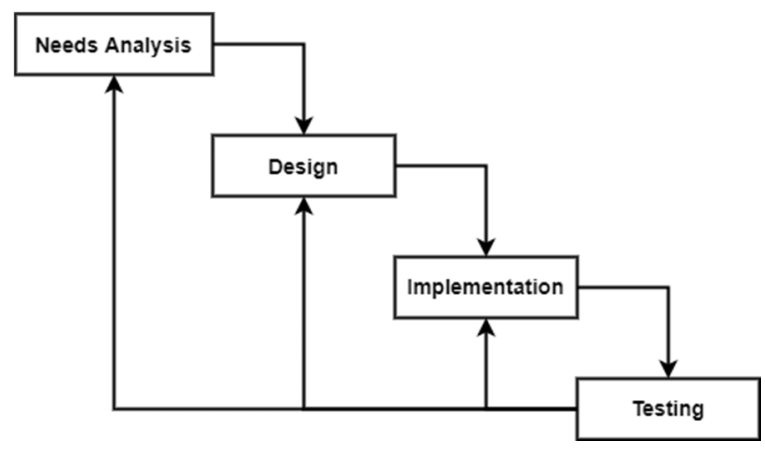

Figure 1. Waterfall Method [10]

\section{Needs Analysis}

This stage is carried out to produce a system by user needs. The analysis carried out on this system includes analysis of the ongoing design, 
analysis of problems and solutions, analysis of the user (user), and analysis of the proposed approach.

\subsection{Current System Analysis}

The certification process at the Bung Hatta University LSP is still carried out manually, starting from the registration process to issuing certificates by BNSP standards and regulations. The following flow map can explain this process.

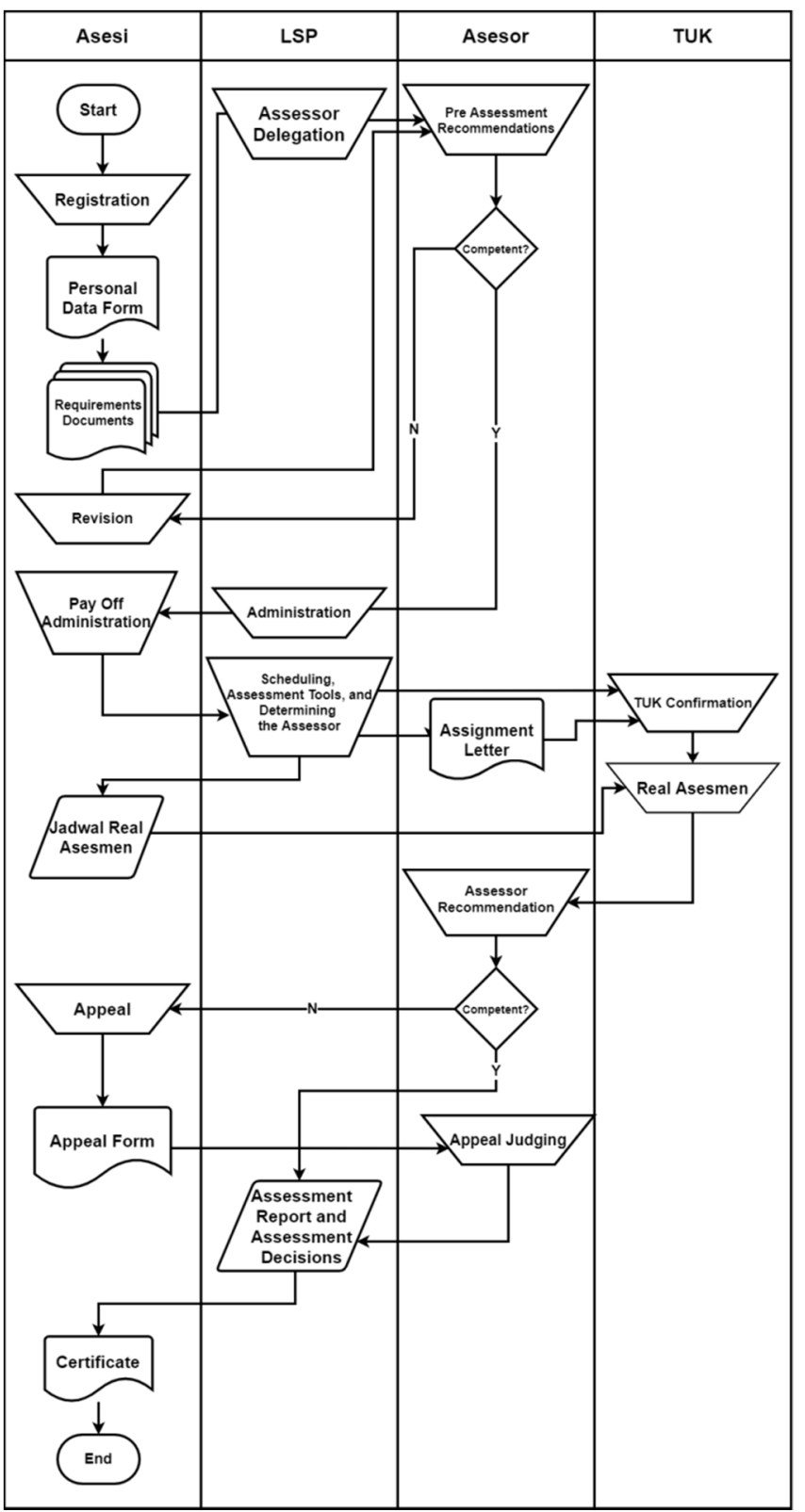

Figure 2. Current System Analysis Flowmap

\subsection{Problems Analysis and Solutions}

Problems analysis and solutions are needed to find out the current system's problems and suitable solutions to solve them. The following are the problems found and the explanations provided.
Table 1. Problems Analysis and Solutions

\begin{tabular}{|c|l|l|}
\hline No & \multicolumn{1}{|c|}{ Problems } & \multicolumn{1}{c|}{ Solutions } \\
\hline 1 & $\begin{array}{l}\text { Limited tormation } \\
\text { related the } \\
\text { implementation of } \\
\text { certification, such as the } \\
\text { requirements that the } \\
\text { assessment participants } \\
\text { must prepare }\end{array}$ & $\begin{array}{l}\text { It is creating an LSP Information } \\
\text { System that displays information } \\
\text { related to the implementation of } \\
\text { certification. Such as information } \\
\text { about the certification scheme, } \\
\text { certification requirements, } \\
\text { competency units, competency } \\
\text { elements, performance criteria } \\
\text { (KUK), certification costs, and } \\
\text { the certification schedule. }\end{array}$ \\
\hline 2 & $\begin{array}{l}\text { The registration process } \\
\text { istill manual, so } \\
\text { participants must go to } \\
\text { LSP Bung Hatta to } \\
\text { register. }\end{array}$ & $\begin{array}{l}\text { The system can be accessed } \\
\text { online so that participants can } \\
\text { register anywhere. }\end{array}$ \\
\hline 3 & $\begin{array}{l}\text { The storage of files } \\
\text { related to the access } \\
\text { data is still manual so } \\
\text { that when the file is } \\
\text { needed, it will be } \\
\text { difficult to find. }\end{array}$ & $\begin{array}{l}\text { Files that have been uploaded to } \\
\text { the system will be stored in the } \\
\text { database and will be easily } \\
\text { retrieved when needed again. }\end{array}$ \\
\hline 4 & $\begin{array}{l}\text { Nostem facilitates } \\
\text { assessors to obtain } \\
\text { the implementation of } \\
\text { certification } \\
\text { assessment tools). }\end{array}$ & $\begin{array}{l}\text { The system provides a page for } \\
\text { downloading the assessment } \\
\text { tool. }\end{array}$ \\
\hline
\end{tabular}

\subsection{User Analysis}

User analysis is used to describe who is involved in the system and the activities that users can perform. The following is an analysis of the users of the Bung Hatta University LSP information system.

Table 2. User Analysis

\begin{tabular}{|c|c|c|}
\hline No & User & Activity \\
\hline 1 & Participant & $\begin{array}{l}\text { - View scheme information and } \\
\text { requirements } \\
\text { - } \text { Register } \\
\text { - Make data corrections } \\
\text { - Conduct self-assessment } \\
\text { - View the assessment schedule }\end{array}$ \\
\hline 2 & LSP Admin & $\begin{array}{ll}\text { - } & \text { Manage assessor data } \\
\text { - } & \text { Manage the certification } \\
\text { scheme } & \\
\text { - } & \text { Manage scheme requirements } \\
\text { - } & \text { Manage competency unit data } \\
\text { - } & \text { Manage competency element } \\
\text { data } & \text { - Manage performance criteria } \\
\text { data (KUK) } \\
\text { - Upload assessment tools } \\
\text { - Checking participant } \\
\text { registration files } \\
\text { - Determine the place for the } \\
\text { competency test (TUK) } \\
\text { - Determine the schedule for the } \\
\text { competency test (real } \\
\text { assessment) } \\
\text { - Determine the assessors }\end{array}$ \\
\hline 3 & $\begin{array}{l}\text { LSP } \\
\text { Management }\end{array}$ & $\begin{array}{l}\text { - Approve the delegation of } \\
\text { assessors }\end{array}$ \\
\hline
\end{tabular}




\begin{tabular}{|c|l|l|}
\hline No & \multicolumn{1}{|c|}{ User } & \multicolumn{1}{|c|}{ Activity } \\
\hline & & $\begin{array}{l}\text { - Making assessor's assignment } \\
\text { letter }\end{array}$ \\
\hline 4 & Assessor & $\begin{array}{l}\text { - Get a letter of assignment } \\
- \text { View the real assessment } \\
\text { schedule } \\
\text { - Download the assessment tool }\end{array}$ \\
\hline 5 & TUK Admin & $\begin{array}{l}\text { - Checking the TUK preparation } \\
- \text { Confirming the real assessment } \\
\text { schedule }\end{array}$ \\
\hline
\end{tabular}

\subsection{Proposed System Analysis}

The proposed system analysis is used to get an overview of the certification process on the system to be designed. The following is a flow map of the proposed approach.

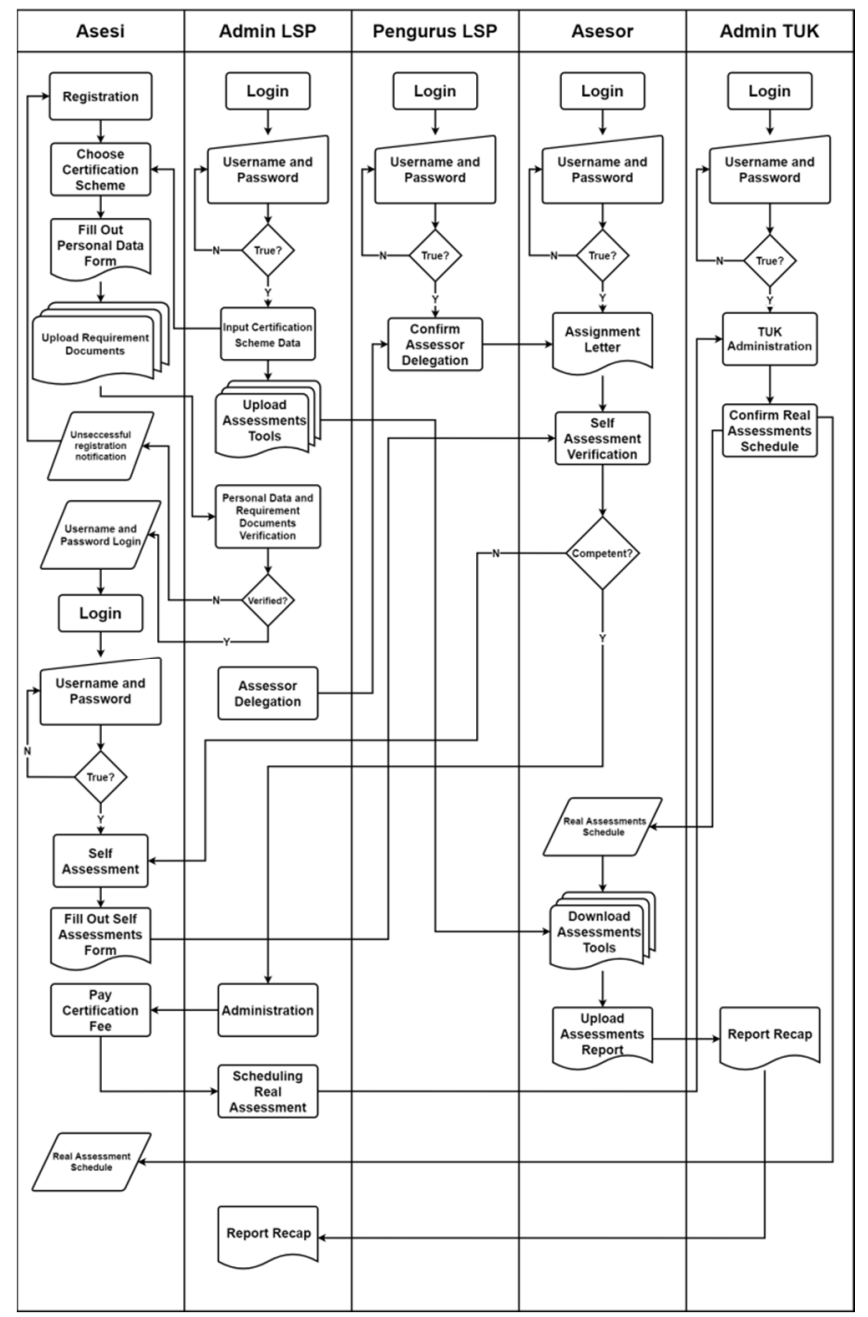

Figure 3. Proposed System Analysis Flowmap

From the flow map of the proposed system, it can be seen that the proposed approach focuses on the initial administration process consisting of initial registration and self-assessment. The initial administrative process is continued until the participants obtain a realistic assessment schedule.

\section{Design}

The design stage is the stage where the system is designed using certain diagrams, which will describe the system as a whole. The design of this system uses Unified Modeling Language (UML) diagrams. UML is a tool for visualizing and documenting the analysis and design results, which contains syntax in modeling systems visually [11]. UML diagrams used in the design of this information system include use case diagrams and class diagrams.

\subsection{Use Case Diagram}

Use case diagrams are diagrams that describe the interaction between the user and the system. The following is a use case diagram of the system being designed.

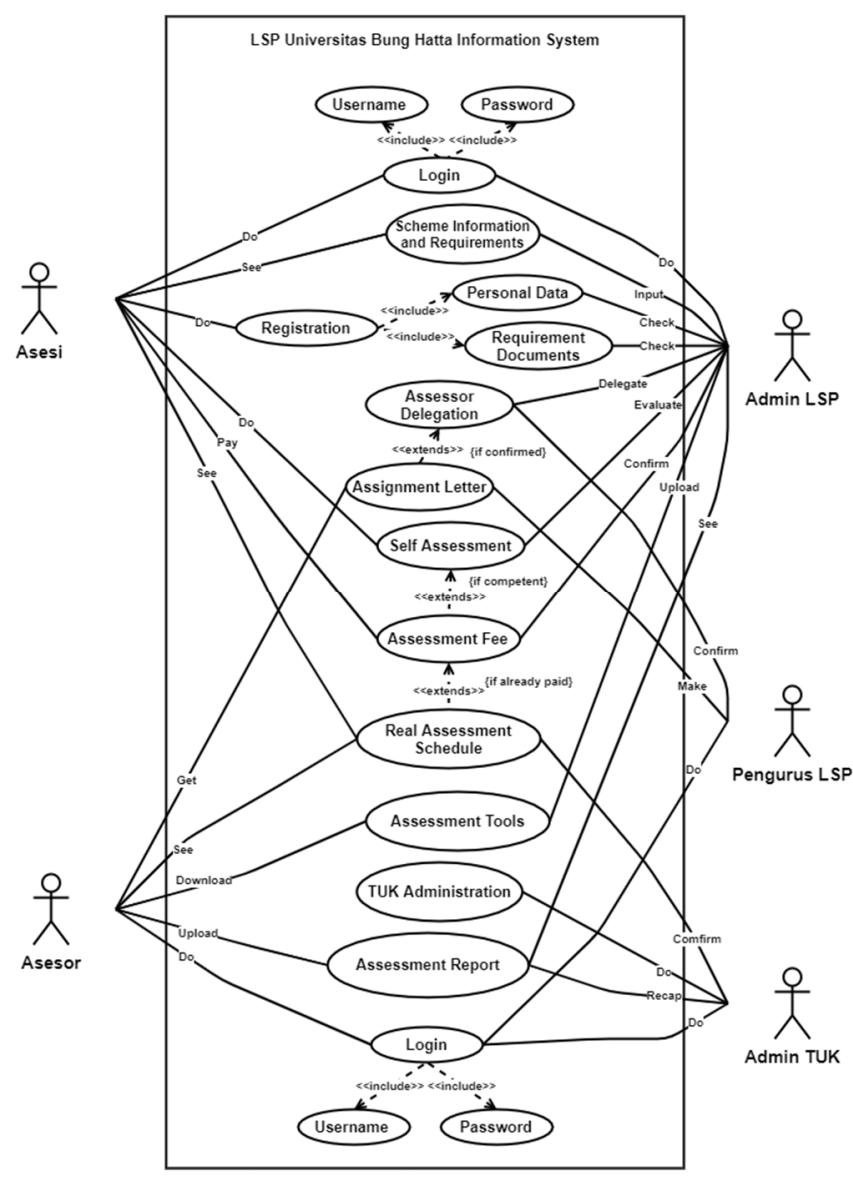

Figure 4. Use Case Diagram of Bung Hatta University LSP Information System

\subsection{Class Diagram}

The class diagram is a diagram that describes the classes contained in the system and their relationships. The categories related to the class diagram represent the tables in the database. The 
following is a class diagram of the system being designed.

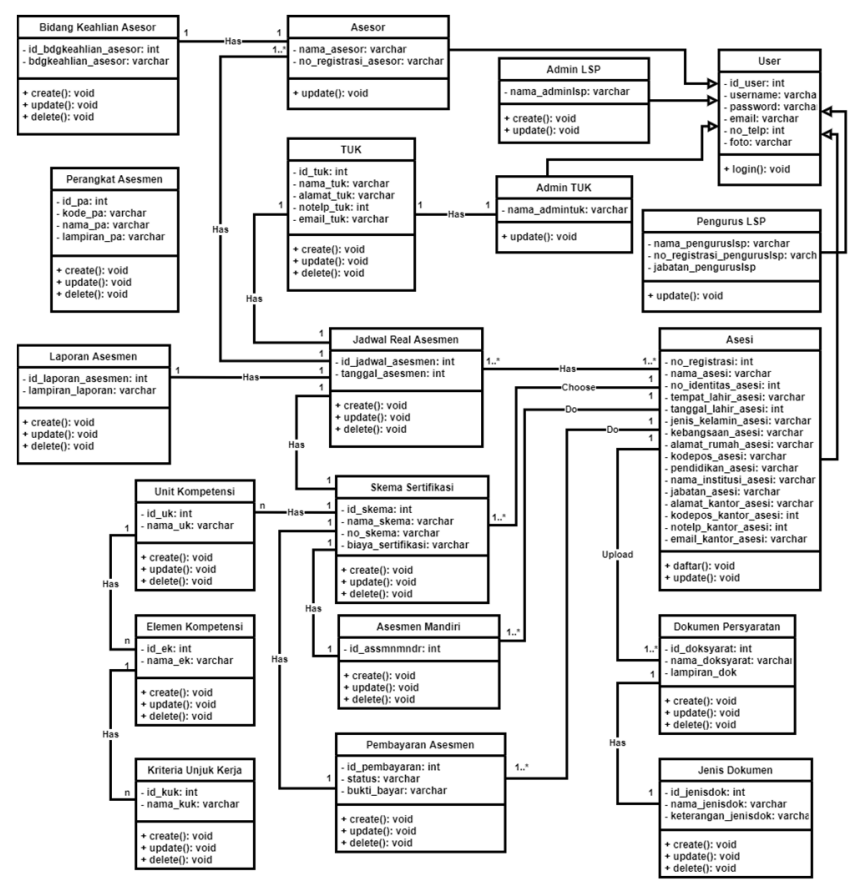

Figure 5. Class Diagram of Bung Hatta University LSP Information System

\section{Implementation}

At the implementation stage, what was designed in the previous step is then applied using a programming language that suits the system's needs. This information system uses the Yii2 framework as the PHP framework and MySQL as the Database Management System (DBMS).

\section{Testing}

At this stage, the results of the implementation phase will be tested whether they are by what has been designed. The results of the testing phase can be analyzed for system development.

\section{RESULTS AND DISCUSSION}

The system design that was carried out resulted in a web-based Bung Hatta University LSP information system. Following are the results and discussion of the Bung Hatta University LSP Information System.

\section{Main Page}

The main page is the page that the user first accesses when accessing the system URL. This page displays menus that the user can select to get the information needed. The following is a look at the main page.

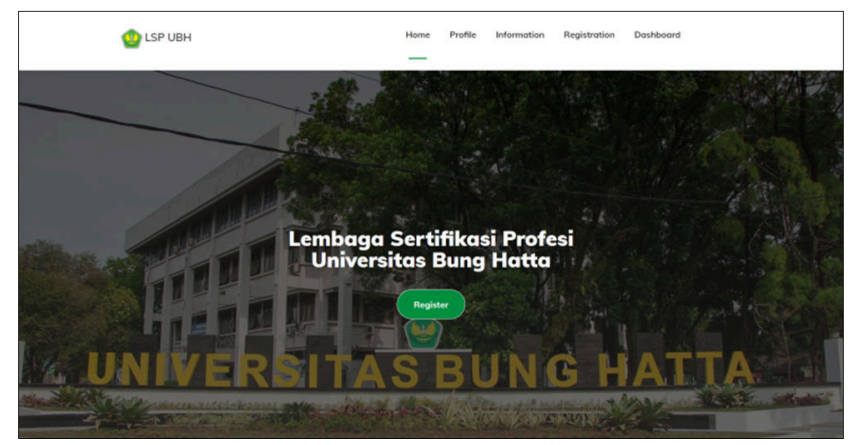

Figure 6. Home Page

\section{Registration Page}

The registration page is the page that appears when a user accesses the registration menu on the main page. The registration page is divided into three registration steps. After carrying out each stage, the registrant data will be forwarded to the admin for verification. If the data entered is by the requirements, the admin will send an email containing the login username and password to the email address that has been registered.

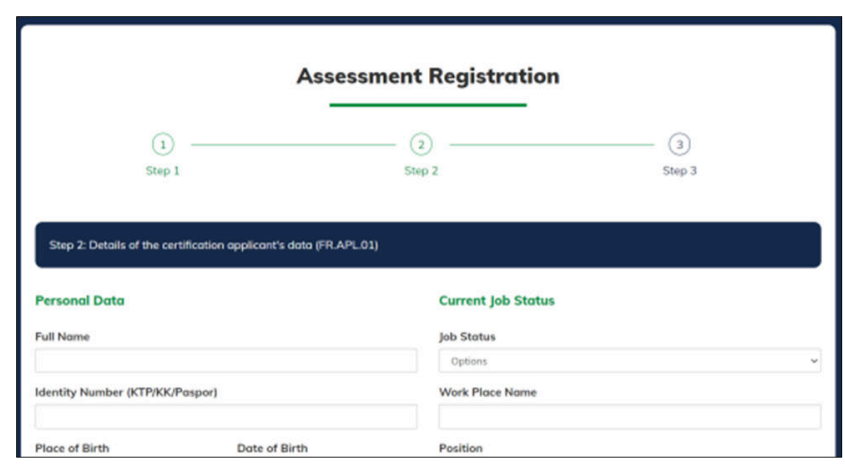

Figure 7. Registration Page

\section{Login Page}

The login page is the page that the user accesses to access the system backend page. On this page, the user is asked to enter a username and password. Each user will be connected to a different backend page according to their access rights. 


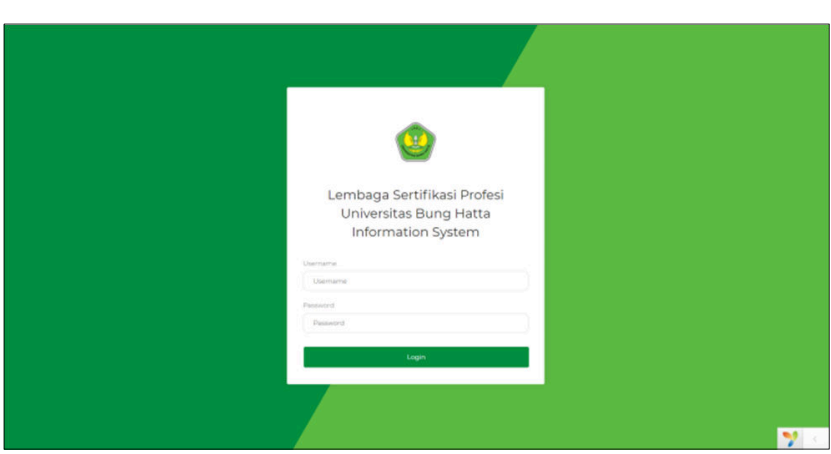

Figure 8. Login Page

\section{Registration Confirmation page}

This page can be accessed by selecting the registration confirmation menu on the LSP Admin page. On the registration confirmation menu, there is a detail button to view the participant data. After checking the data, the LSP admin can press the confirmation button if the data entered is by the registration requirements.

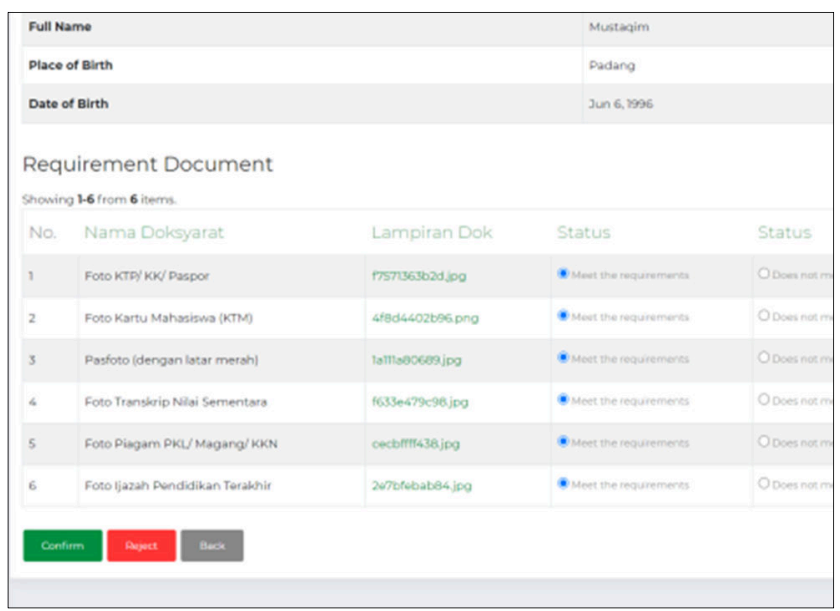

Figure 9. Registration Confirmation Page

\section{Assessor Delegation Page}

This page can be accessed by selecting the registration confirmation menu on the LSP Admin page. This page will appear after the LSP Admin confirms the registration of the session. On this page, the LSP Admin is asked to enter a recommendation for the assessor's name, which will be forwarded to the LSP Management for confirmation.

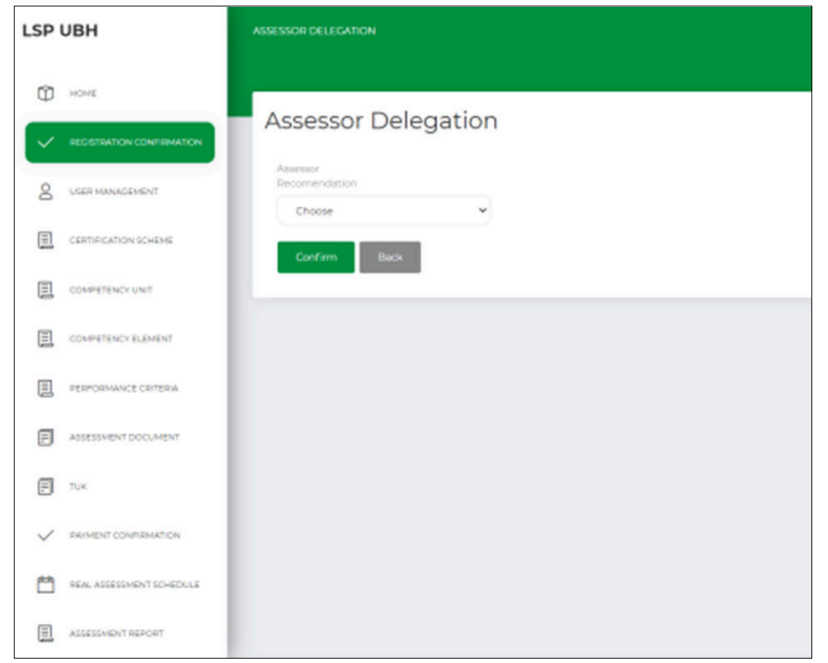

Figure 10. Assessor Delegation Page

\section{Assessor Delegation Confirmation Page}

This page can be accessed by selecting the assessor delegation menu on the LSP Management page. In this menu, there is a button to display the assessor delegation confirmation page. On this page, the assessor recommendations that the LSP admin has inputted will appear. If the LSP Management does not agree with the assessor recommendation given by the LSP Admin, then the LSP Management can change the assessor delegation before confirming it.

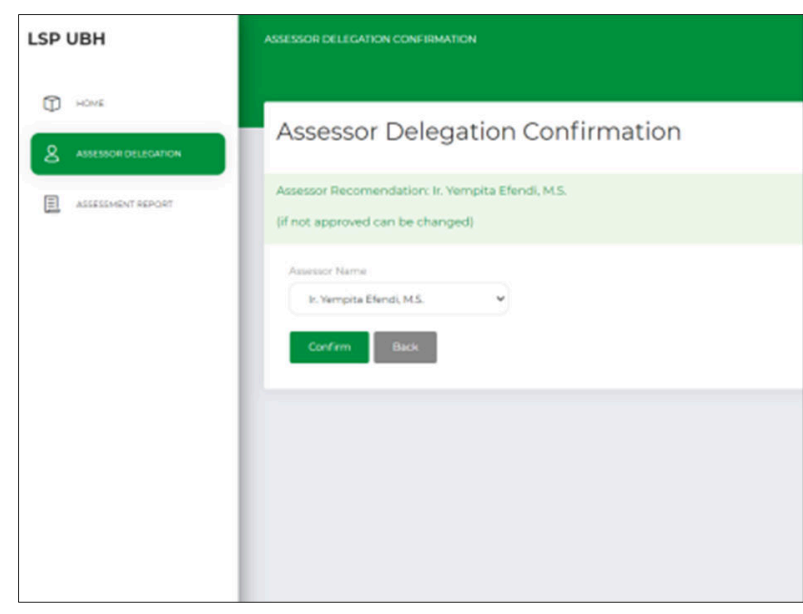

Figure 11. Assessor Delegation Confirmation Page

\section{Self-assessment Page}

Assessment participants can access this page after the LSP Management confirms the assessor delegation. This page can be accessed by selecting the self-assessment menu of the assessment page. In this menu, there is a button to display a form of self-assessment. In this form, assessment 
participants are asked to measure their abilities based on the questions given. If competent, participants can mark column K (capable). Then participants are asked to upload relevant evidence related to the statements given.

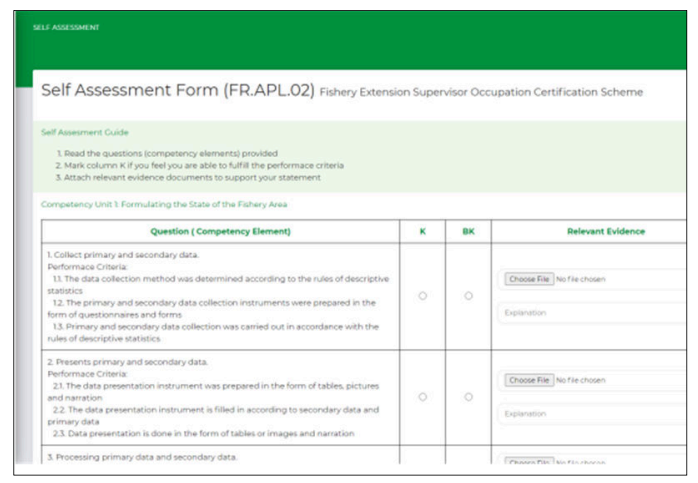

Figure 12. Self-Assessment Page

\section{Self-Assessment Evaluation Page}

This page can be accessed by selecting the self-assessment menu on the assessor page. This menu displays the participant's self-assessment data. In this menu, there is a button to display the self-assessment form. The assessor can see the relevant evidence that participants have uploaded. If the participant fills in $\mathrm{K}$ (competent) for each question given and the evidence uploaded is appropriate, the assessor can recommend it by pressing the recommended button. If not, the assessor can select the button not yet recommended.

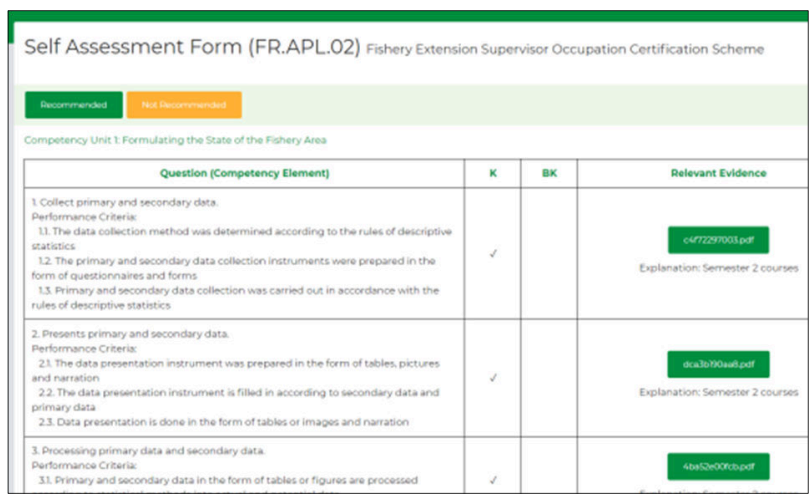

Figure 13. Self-Assessment Evaluation Page

\section{Assessment Fee Payment Page}

This page can be accessed by selecting the assessment payment menu on the participant page. A pay button will appear on this menu if the participant is recommended competent by the assessor during the self-assessment stage. If the participant presses the pay button, the assessment fee payment page will appear. On this page, participants are asked to upload proof of assessment payment.

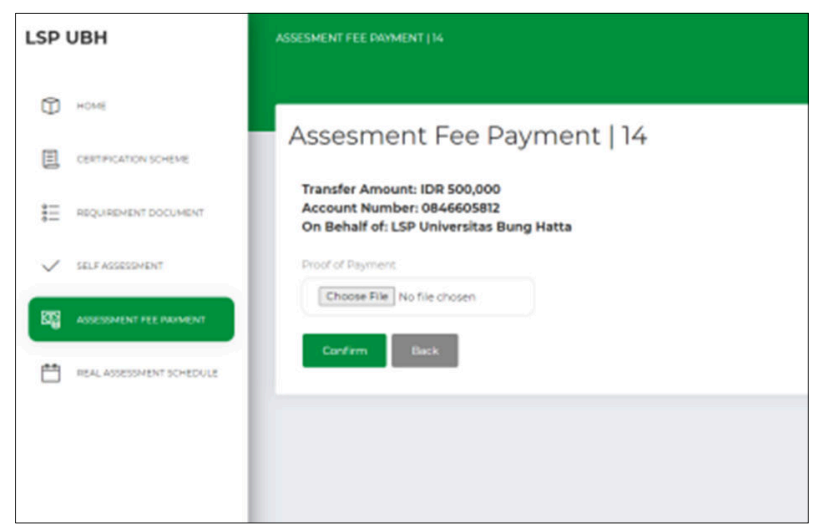

Figure 14. Assessment Fee Payment Page

\section{Assessment Fee Payment Confirmation Page}

This page can be accessed by selecting the payment confirmation menu on the LSP Admin page. On this page, the admin can see proof of payment that the participant has uploaded. After confirming the assessment payment, the admin can press the confirm button.

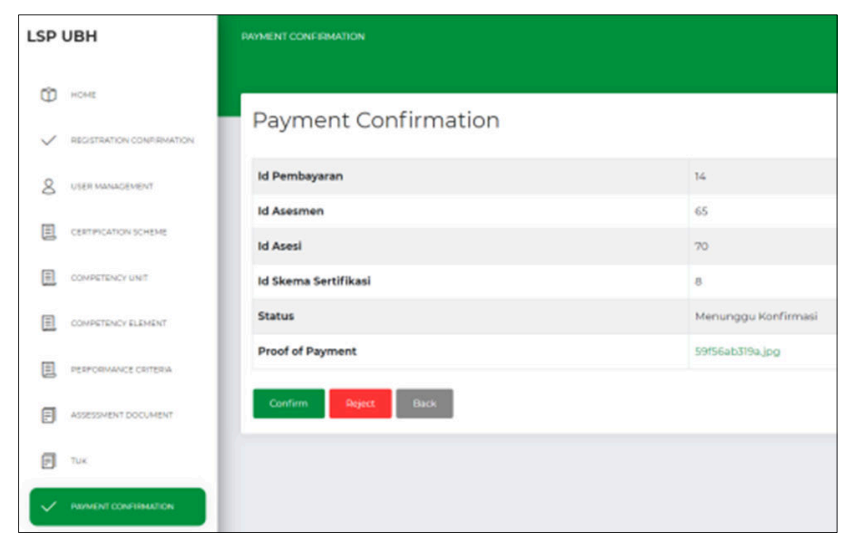

Figure 15. Assessment Fee Payment Confirmation Page

\section{Real Assessment Scheduling page}

This page can be accessed by selecting the assessment payment menu on the LSP Admin page. This page will appear after the LSP Admin confirms the payment of the assessment fee. The LSP admin is asked to input the TUK and recommend a schedule. 


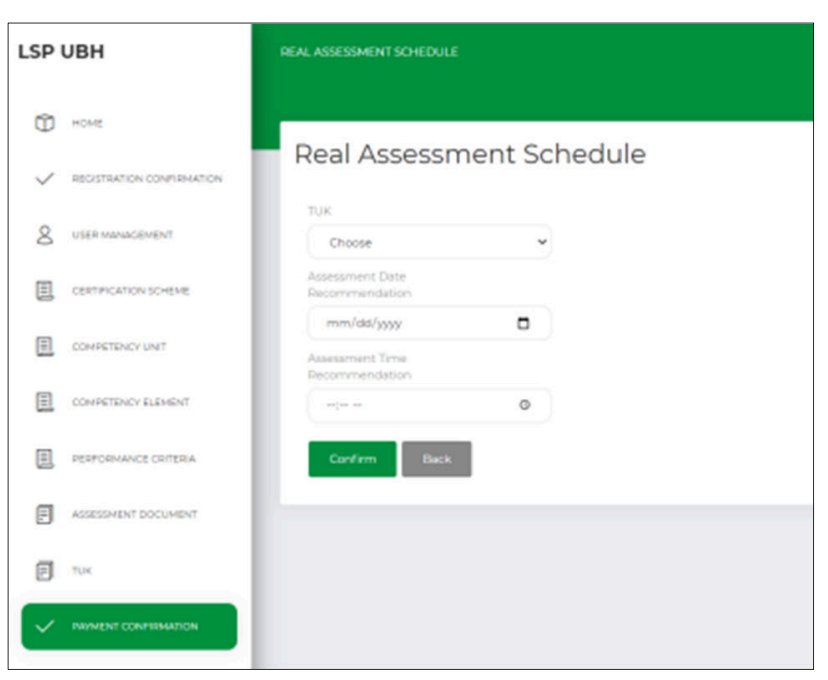

Figure 16. Real Assessment Scheduling Page

12. Real Assessment Schedule Confirmation Page

This page can be accessed by selecting the confirmation menu for the entire assessment schedule on the TUK Admin page. On this page, the TUK Admin is asked to confirm the schedule recommended by the LSP Admin. If the suggested plan is not according to the TUK conditions, the TUK Admin can change the plan before confirming.

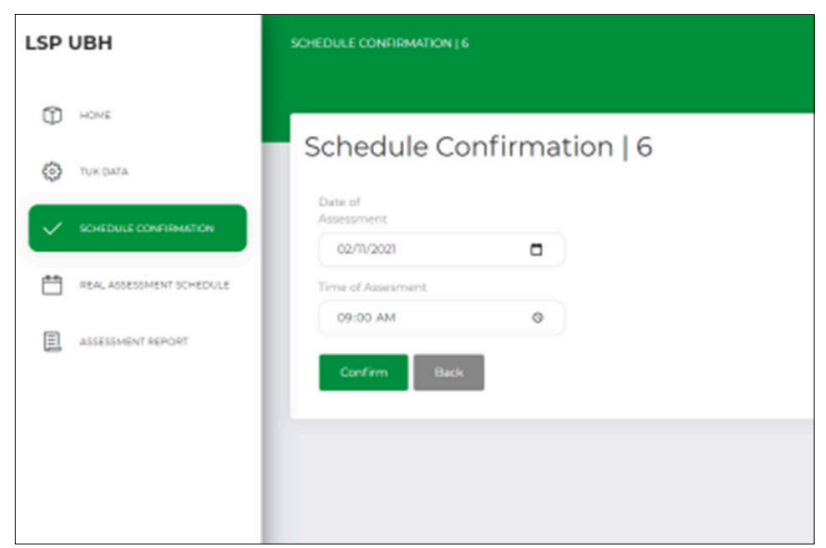

Figure 17. Real Assessment Schedule Confirmation Page

\section{Real Assessment Schedule Page}

This page can be accessed by selecting the entire assessment schedule menu on the participant page. This page displays information on the whole assessment schedule that the participants will follow.

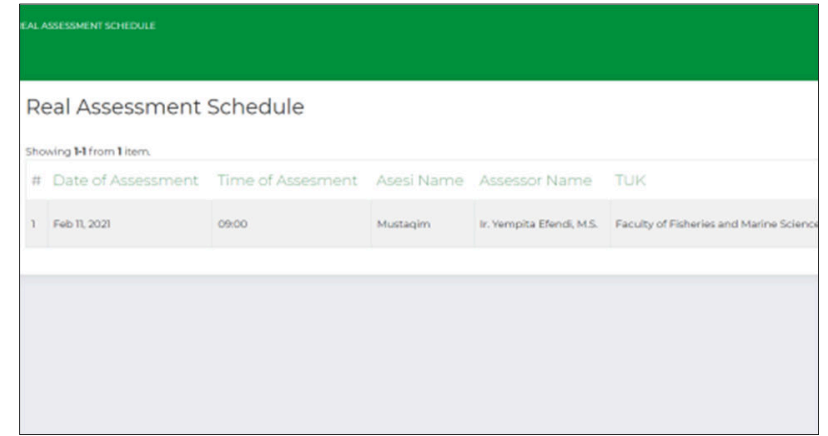

Figure 18. Real Assessment Schedule Page

\section{Assessment Tools Page}

This page can be accessed by selecting the assessment tool menu on the assessor page. On this page, assessors can download the assessment tools they need.

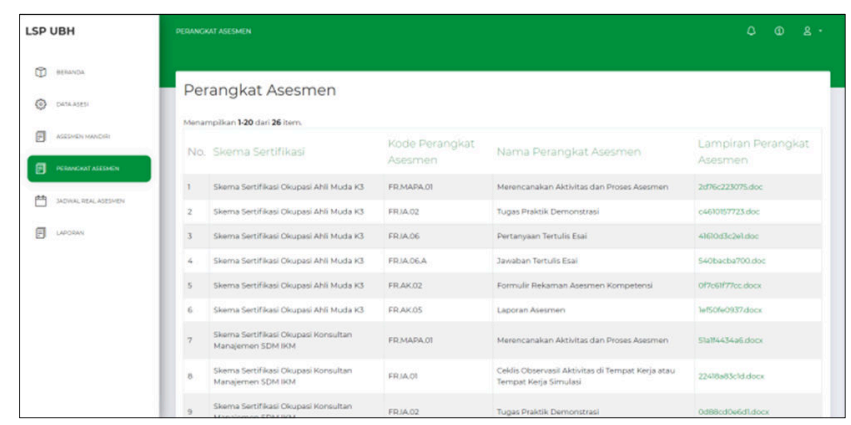

Figure 19. Assessment Tool Page

\section{Assessment Report Page}

This page can be accessed by selecting the report menu on the assessor page. On this page, assessors are asked to input assessors' recommendations, and upload completed assessment report files.

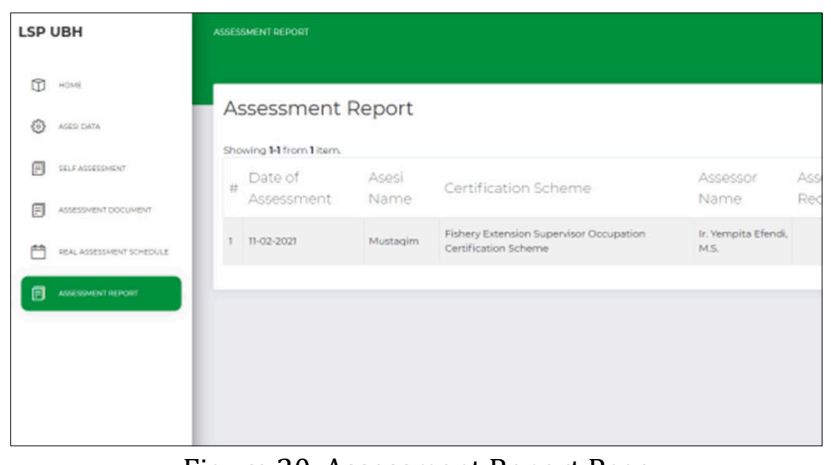

Figure 20. Assessment Report Page

\section{Assessment Report Recap Page}

This page can be accessed by selecting the report menu on the TUK Admin page. This page displays a recap of the report data that the assessor has inputted. Admin can filter data based on the assessment schedule. 


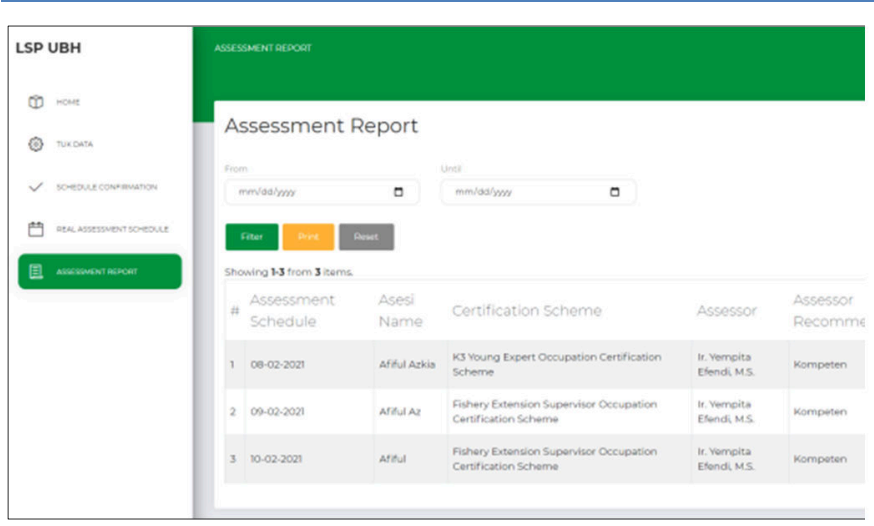

Figure 21. Assessment Report Recap Page

\section{CONCLUSION}

The conclusions obtained from the design results of the Bung Hatta University LSP Information System are as follows.

1. The Bung Hatta University LSP Information System is implemented using the Yii2 framework.

2. The Bung Hatta University LSP Information System focuses on the initial administrative process.

3. The Bung Hatta University LSP Information System can store assessment data in a more structured manner.

4. The Bung Hatta University LSP Information System makes it easier for assessors to obtain assessment tools.

\section{SUGGESTION}

The Bung Hatta University LSP Information System, which was designed, still focuses on the initial administrative process, so many assessment processes are still being carried out manually. It is hoped that the Bung Hatta University LSP Information System can be further developed to cover the entire assessment process, from the registration process to the certificate management process.

\section{REFERENCES}

[1] LSP Universitas Bung Hatta, Pedoman Pelaksanaan Sertifikasi Lembaga Sertifikasi Profesi Universitas Bung Hatta, LSP Universitas Bung Hatta, Padang, 2019.

[2] Republik Indonesia, Undang-Undang No. 13 Tahun 2003 tentang Ketenagakerjaan, Lembaran Negara RI Tahun 2003, No. 39, Sekretariat Negara, Jakarta, 2003.

[3] Republik Indonesia, Peraturan Pemerintah No. 23 Tahun 2004 tentang Badan Nasional
Sertifikasi Profesi, Lembaran Negara RI Tahun 2004, No. 78, Sekretariat Negara, Jakarta, 2004.

[4] Kristanto, Andri. Perancangan Sistem Informasi dan Aplikasinya, Gava Media, Yogyakarta, 2008.

[5] Pasaribu, J. S., "Penerapan Framework Yii pada Pembangunan Sistem PPDB SMB BPPI Baleendah Kabupaten Bandung", Jurnal Ilmiah Teknologi Infomasi Terapan, Vol. III, No. 2, 2017.

[6] Rosmala, D., Ichwan, M., Gandalisha, M. I., "Komparasi Framework MVC (Codeigniter dan CakePHP) pada Aplikasi Berbasis Web (Studi Kasus: Sistem Informasi Perwalian Di Jurusan Informatika Institut Teknologi Nasional)", Jurnal Informatika, Vol. 2, No. 2, 2011.

[7] Mukhlasin, Hafid. Membangun Aplikasi Profesional Berbasis Web Menggunakan Yii Framework, Buku Baik, Jakarta, 2016.

[8] Warman, I., \& Ramdaniansyah, R., "Analisis Perbandingan Kinerja Query Database Management System (DBMS) Antara Mysql 5.7. 16 Dan Mariadb 10.1", Jurnal Teknoif, 6(1), 3241, 2018.

[9] Tristanto, C., "Penggunaan Metode Waterfall untuk Pengembangan Sistem Monitoring Dan Evaluasi Pembangunan Pedesaan", Jurnal Teknologi Informasi ESIT, Vol. XII, No. 1, 2018.

[10] Perkasa, M. R., Kridalukmana, R., Widianto, E. D., "Perancangan Sistem Manajemen Restoran dengan Aplikasi Pemesanan Restoran Berbasis Mobile dalam Jaringan Lokal", Jurnal Teknologi dan Sistem Komputer, Vol. 4, No. 2, 2016.

[11] Haviluddin, "Memahami Penggunaan UML", Jurnal Informatika Mulawarman, Vol. 6, No. 1, 2011. 